\title{
From Rodinia to Western Gondwana: An approach to the Brasiliano-Pan African Cycle and orogenic collage
}

1- Instituto de Geociências - Universidade de São Paulo. S. Paulo-SP. 2- Instítuto de Geociências - Universidade de Brasílía. Brasílía-DF.

The basement of the South American platform displays the lithostructural and tectonic records of three major orogenic collages: Middle Paleoproterozoic (or Transamazonian), Late Mesoproterozoic/Early Neoproterozoic and Late Neoproterozoic/Cambrian, the Brasiliano-Pan African collage. The first two collages have their records in the basement of the Syn-Brasiliano cratons and Brasiliano Fold Belts.

The development of the Brasiliano-Pan African collage started in Early Neoproterozoic times, with the first events of breakup of the Rodinia Supercontinent, and it has been characterized by diachrony since their early beginnings. The processes of break up and fission took place in different time intervals (ca. 1000-950 Ma, ca. $750 \mathrm{Ma}, \mathrm{ca} .600 \mathrm{Ma}$ ) from one part to another. Different lithospheric segments were then generated as large (cratons), intermediate and small (terranes, massifs) blocks and, at the same times, different kinds of basins were formed among them, floored by continental, proto-oceanic and oceanic rock units. The subsequent interactions among these blocks, descendants of Rodinia, have occurred all over the Neoproterozoic, since the Tonian up to the Cambrian period, according with local tectonic circumstances, from one province to another, until the complete (collision) closure of all basins due to different phases of tectonic convergence. Diachronism was a characteristic of the basin-forming tectonics and also of the subduction and collisional processes that have formed the Brasiliano-Pan African orogenic systems. So, the basement of the South American platform is recording all the steps of the development of a complete, wide and complex Wilson Cycle, from the disarticulation of the former Mesoproterozoic supercontinent (Rodinia) to the amalgamation of a newer one (Western Gondwana), following a very diachronic history of evolution.

For descriptive purposes, four structural provinces have usually been recognized for those domains where these orogenic systems sharing the Brasiliano collage are better cropping out: Borborema (Eastern north- east), Tocantins (Central-eastern, part of the Centralwestern), Pampean (Central-southwestern) and Mantiqueira (East-southeast).

\section{Introduction}

The history of the geologic evolution of the South American continent from the Neoproterozoic to the early Cambrian is recording all the steps of the development of a complete and wide tectonic cycle, in terms of J.T. Wilson. This means, from the fission/disarticulation of a former Late Mesoproterozoic Supercontinent (Rodinia) - up to the further fusion/agglutination of a newer supercontinent - Western Gondwana (Pannotia).

For the two major tectonic phenomena then developed (fission and subsequent fusion) it is necessary to remark, since now, the diachronic character for all their typical events of divergent (rift and drift) and convergent (subduction, dockage, collision) plates and subplates interaction. The plurality and diachrony of these processes of convergence and orogeny used to occur even for a same structural province. Therefore, under these prevailing conditions the name and use of the expression "tectonic collage" seem to be the most appropriate (according to Sengör, 1990; adapted from Helwig, 1974). Such a designation embraces the development of different branched systems of orogens then formed, in different spaces (provinces) and different spans of times, with the final fate of forming a newer supercontinent.

The processes of fission ( Figure 1) took place in different times from the Tonian to the Neoproterozoic III (ca. 1000-900 Ma, ca. 750 $\mathrm{Ma}$, ca. $600 \mathrm{Ma}$ ) according to local tectonic circumstances and surrounding conditions. These processes have somehow privileged tectonic zones of the former megacycle (Grenvillian) of the agglutination of Rodinia. Varied processes of basin-forming tectonics took place, resulting in single continental rift systems (small values for the $\beta$ factor) up to the development of oceanic realms of different magnitudes.

The convergence processes were varied in degree of intensity and timing, with diachrony as a worthy characteristic (Figure 2), and particularly many of them were somehow concurrent in time with those processes of distension and divergence elsewhere, in different structural provinces (or even in the same province). The designation of Brasiliano collage intends to embrace all the set of accretionary and collisional orogenic events (from ca. $850 \mathrm{Ma}$ up to $490 \mathrm{Ma}$ ) and their final accomplishment of a supercontinental landmass, Western Gondwana in this case.

Regarding the extensional processes it is necessary to note, firstly, the importance of the size and nature (geologic and structural composition) of the segments then produced by fission, i.e., Neoproterozoic plates and subplates, microcontinents, terranes, etc., the descendants of Rodinia. Some large blocks (e.g., Amazonia, West 


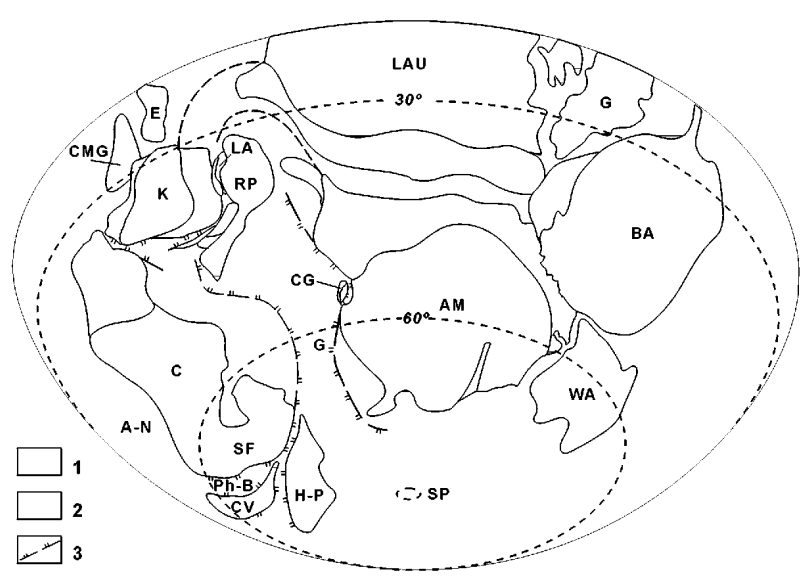

Figure 1 A modified view of the Rodinia reconstruction (from Weil et al, 1998). The shapes of Amazonas, São Francisco-Congo, Rio de La Plata and West Africa continental segments are modified. Speculative positions are assumed for the HoggarPotiguar (here-postulated) plate and Cariris Velhos terrane (Mesoproterozoic orogen). 1. Grenvillian orogens; 2. Continental plate segments; 3. Tonian rift lines. AM - Amazonas; BA Baltica; C - Congo; CV - Cariris Velhos; CMG - Coates LandMaudheim-Grune-Hogna Province; E - Ellworth-Withmore mountain belt; $G$ - Greenland; H-P - Hoggar-Potiguar; $K$ Kalahari; LAU - Laurentia; RP - Rio de La Plata; WA - West Africa; LA - Luis Alves terrane; CG - Central Goiás terrane; AN - Arabian-Nubian Ocean; G -- Goianides Ocean; PhB Pharusian-Borborema Ocean; SP - South pole.

Africa-São Luis, São Francisco-Congo, Rio de la Plata), blocks of intermediate extent (e.g., Pampia, Central de Goiás) and small blocks (e.g., Guanhães, Curitiba, Juiz de Fora, Luís Alves) have been generated or outlined. In the interior of these major continental segments it is possible to find out litho-structural records of Archean nuclei and fragments of fold belts of all previous Paleoproterozoic and Mesoproterozoic cycles, including those responsible for the previous agglutination of Atlantica (Paleoproterozoic; Rogers, 1996) and Rodinia (Late Mesoproterozoic/Early Neoproterozoic; Hoffman, 1991). The smaller descendants of Rodinia used to be alterna- tively composed only of fractions of Archean nuclei (Luis Alves, as example) and/or fractions of other Proterozoic fold belts (as in the cases of Pampia, Juiz de Fora, etc.).

These descendants of Rodinia (Figure 3) have evolved to and worked out as plates, subplates, microplates, microcontinents and terranes during the whole Neoproterozoic and the Cambrian. They interacted during that time (ca. $410 \mathrm{Ma}$ as a whole) and generated volcanic and magmatic arcs and other subsequent collisional domains, which became the so-called Brasiliano/Pan African mobile belts. The participation of some other blocks of exotic provenance (extra-Rodinia), from continental or oceanic realms in that Western Gondwana collage, was not recorded up to now, but this is still an open possibility.

The overall processes of tectonic deformation - in both geologic time and paleogeographic space - led by those varied settings of interactions were not limited to the orogenic belts then developed. Important tectonic and thermal reworking was imposed to the underlying basement and surrounding tectonic domains, under different crustal levels and scales. The actions and effects of the Brasiliano deformation (as well as the associated granitogenesis) have advanced to the interior of those lithospheric segments, so promoting crustal reworking of varied intensities. Also, some previous volcanic and sedimentary covers (Paleoproterozoic and Mesoproterozoic in age) of those Rodinia descendants have been affected, under thinskin (external zones of the Brasiliano belts) and under thick-skin (those positioned in more internal zones of the Brasiliano fold belts) tectonic conditions. This is also true for real cratonic covers of Neoproterozoic age, far from the main scenario of interactions as, for example, in the case of the São Francisco groups of the São Francisco-Congo-Kasai cratonic block. Some of these processes of reworking are beyond the scope and control of the methods of Surface Geology itself. Only observations based upon isotopic and geochemical methods are able to point them out.

Therefore, although the general structural framework, fold belts, interacting blocks and the like, and the consolidation of Western Gondwana are the ostensible face of the Brasiliano collage, there are many other important components of the general reworking of previous litho-structural assemblages that have to be evoked.

Additionally, many domains of the Brasiliano collage have played a remarkable role in the frame of the subsequent Phanerozoic evolution. This was particularly overstated as control for the location of interior and coastal Mesozoic and Cenozoic rifts ("Stage of Activation" of the South American Platform). But, before that, even dur-

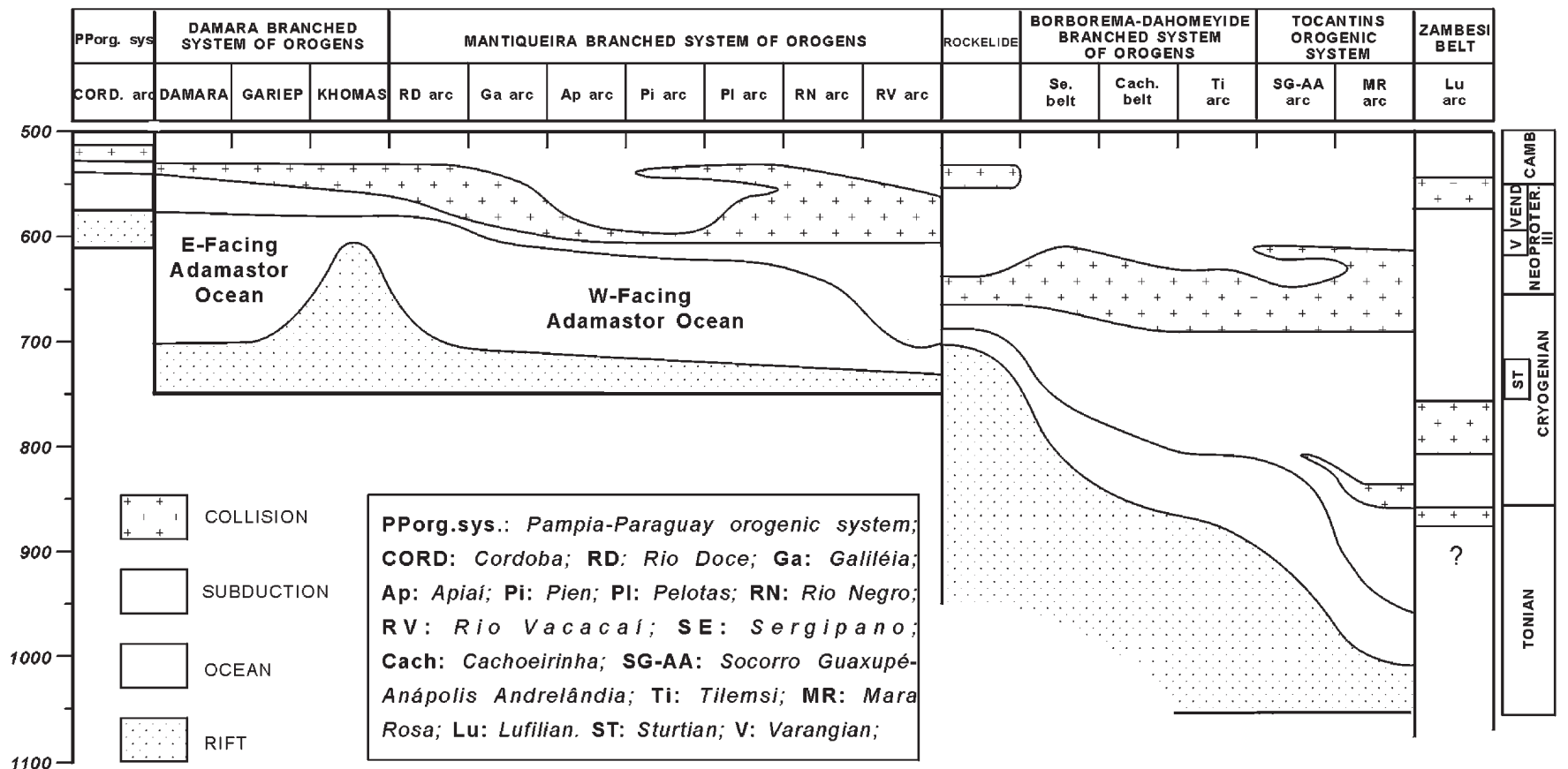

Figure 2 Western Gondwana assembly - Brazilian-Pan African collage: An attempt to a tectonic correlation table. 


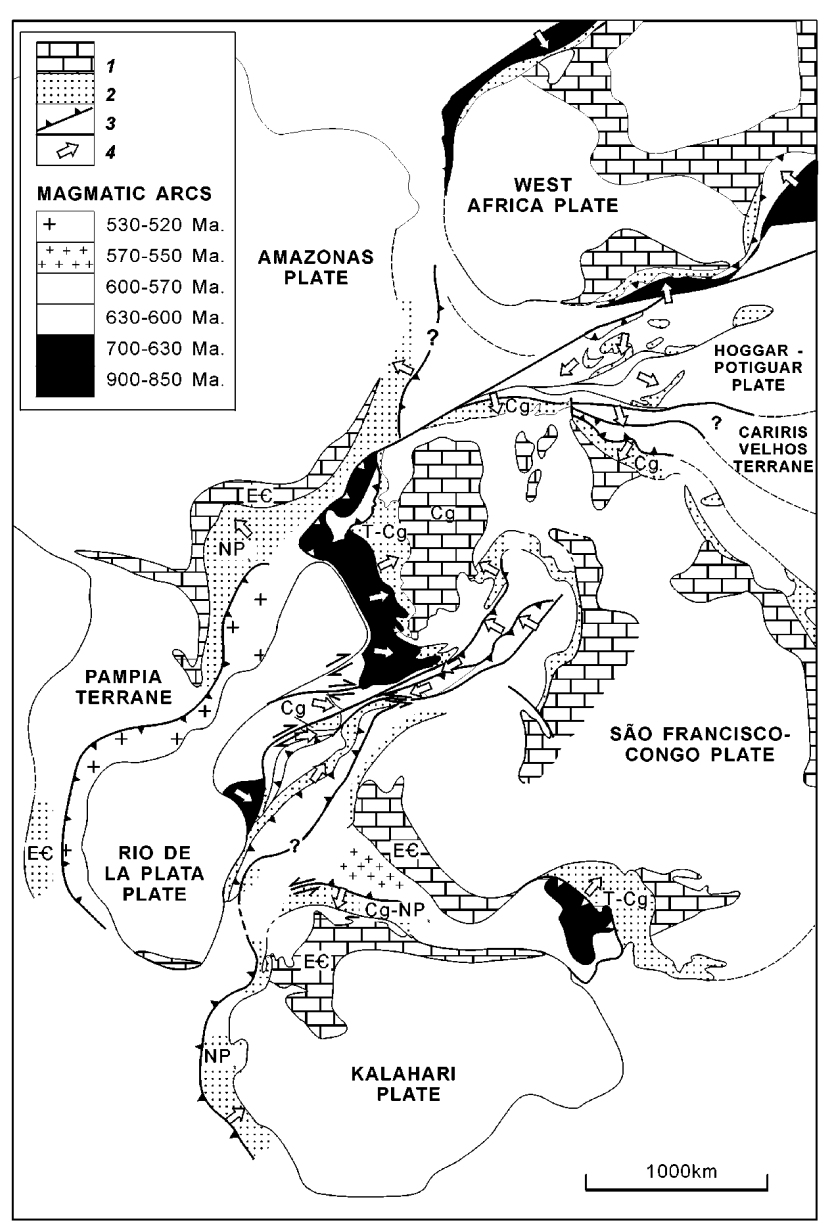

Figure 3 Western Gondwana major continental plates and magmatic arcs. 1 - Platform covers; 2 - Passive continental margin deposits or thinner continental crust domains; 3 Subduction zones with the sense of dip; 4 -Structural vergence.

ing the installation of the major Palaeozoic - post-Cambrian syneclises ("Stage of Stabilization" of the platform), tectonic inheritances had exerted their influences (Brito Neves et al. 1984). The conditions of thermal age were widely effective everywhere and the reciprocal is likely: only far away and out of Brasiliano domains there were conditions for tectonic stability during the Phanerozoic sedimentary history.

The proposal and identification of four structural provinces or four major orogenic systems for the Brasiliano domains in South America are more a praxis and a concession to the descriptive commitments (Almeida et al., 1981), and this must not obscure the many paleogeographic and tectonic links shared by them. Such discrimination is done only to delineate the main area of expositions of Brasiliano structures (as they are allowed by the Paleozoic syneclises), which are additionally positioned in different geographic regions: Borborema (eastern northeast), Tocantins (centraleastern, part of the central western), Pampean (central-southwestern) and Mantiqueira (east-southeast). Besides these internal links easily detected in South America, the study and understanding of these orogenic provinces should be handled with the support of the analysis of their African counterparts.

A completely new arrangement for the blocks derived from the fusion of Rodinia was obtained with the development of the Brasiliano/Pan African fold belts and the consequent agglutination of Western Gondwana. To this huge and complex mosaic of continental blocks and branched orogenic systems there were the further docking of different minor blocks of several provenances, continental (later fractions of Gondwana, fractions of Laurentia) and oceanic assemblages during the Famatinian (Lower Palaeozoic) and Hercyn- ian (Permian, Triassic) orogenic processes (Bahlburg and Hervé, 1997). The individualization and the final outline of the South American continent were subsequently accomplished in the Mesozoic and Cenozoic eras by time-concurrent activities, those related with the formation of the South Atlantic Ocean (accretion) to the northeast and east, and with the building of the Andean Chain s.l., to the north, west and southwest (including B-subduction, micro-collisions and transform interactions). Particularly, for this development of the Atlantic Ocean, a series of Brasiliano structural inheritances have played an important role.

\section{Borborema branched system of orogens}

The Borborema Province, the northeast part of the South American continent, is the better-exposed fraction of the Brasiliano Collage, positioned between the West Africa-São Luis-Parnaiba (north and northwest) and the São Francisco-Congo (at south). From Togo to Cameroon, in Northwest Africa, there are correspondent litho-structural assemblages for this province (Brito Neves et al., 1995).

This province is a complex mosaic of Neoproterozoic fold belts (just one is a reworked Mesoproterozoic belt) and basement inliers ("massifs") which are mostly expositions of the previous Paleoproterozoic/Transamazonian collage (Van Schmus et al., 1995). The structural trends exhibit a fan-like distribution, all of them reaching diagonally the coastal area and the continental margin. Such structural pattern was commanded by a important net of shear zones or lineaments that were the preferential sites for the last extrusional post-collision movements (Late Neoproterozoic III to the Cambrian) in this province. Besides this net of lineaments, another conspicuous characteristic is the Brasiliano plutonism emplaced in different phases from $730 \mathrm{Ma}$ up to $500 \mathrm{Ma}$, which performs over $30 \%$ of the whole province.

Four main geologic/tectonic domains may be identified in this province based upon the nature and composition of the terranes they are assembling:

a. The Médio Coreau domain (MCO), at the west of the Transbrasiliano (Sobral) Lineament, displays a reworked border of the São Luis-West Africa craton ("Granja Massif") and trapped fragments of two main kinds of fold belts of the province: pelitic-carbonatic (proximal, Ubajara belt) and volcano-sedimentary (distal, Martinópole belt). Actually, these are displaced and trapped fractions of the development of the Trans-Saharian (DahomeydesPharusian) continental margins left in our continent during the postMesozoic drift. Additionally, this domain is characterized by immature clastic (some volcanic rocks) deposits (Jaibaras Group) and granitic stocks, all emplaced in Cambrian pull-apart spaces developed along the Transbrasiliano Lineament. The majority of these deposits do not crop out, they are underlying the Paleozoic Parnaiba Syneclise, as well as defining one of their main depocenters.

b. The Setentrional domain is positioned between the Transbrasiliano (NE-SW) and the Patos (W-E) lineaments, and is characterized by the almost continuous expositions of the Paleoproterozoic basement (some local Archean nuclei), which were reworked to different degrees during the Brasiliano collage. These expositions are overspread along the so-called "massifs" (Troia-Tauá, Rio Piranhas, São José do Campestre) and as minority in the basement (local windows) of the supracrustal belts there present. The belts are formed by sedimentary and volcano-sedimentary covers of Late Paleoproterozoic - Jaguaribeana-Oeste Potiguar - and mainly of Neoproterozoic ages, like Rio Curu-Independência, Guaramiranga-Canindé = Ceará Central, and Seridó, this being the classical area of the province. These rock assemblages are mostly composed of quartzitepelitic ( \pm carbonatic) rock units with minor volcanic components, and were submitted to strong transpressional deformation during the Brasiliano collage. No significant materials of oceanic signatures have up to now been detected in the evolution of these belts, as well as their geophysical data used to indicate a previous integrity of the whole asement. These belts are distributed from west to east, with 
N-NE structural trends alternating with basement inliers ("maciços"), all of them marked by the Brasiliano granitogenesis and shear zones activities. The basement of this domain was probably a segment of Atlantica, a Paleoproterozoic supercontinent (Rogers, 1996), that was brought to the present position by the consecutive actions of the Cariris Velhos (Mesoproterozoic) and Brasiliano orogenies.

c. The Transversal Domain is situated between the Patos (E-W) and Pernambuco (E-W) lineaments in the central part of the province. It is characterized by the presence of a volcano-sedimentary fold belt of Late Mesoproterozoic/Neoproterozoic age (besides other Neoproterozoic belts to be mentioned), which seem to represent a complete development of a wilsonian cycle (Cariris Velhos). Particularly, it is striking in the composition of this belt a suite of meta-aluminous to peraluminous leuco-orthogneisses, enclosed by meta-volcanic (mostly felsic types) and meta-sedimentary supracrustals (psammo-pelitic, mostly). To the north of this belt there is a contiguous Neoproterozoic belt $(<650 \mathrm{Ma}$, Piancó belt) composed by low-grade meta-rythmites, intercalated with bimodal volcanics of arc-affinities and pierced by several intrusions of tonalites, quartz-diorites and high- $\mathrm{K}$ granites. These volcano-sedimentary rock assemblages are younger than $630 \mathrm{Ma}$, and the granites were intruded between 620 and $570 \mathrm{Ma}$.

The net of shear zones that delimitates and transects the transversal domain have deeply reworked these two contiguous belts during a late phase of escape tectonics, specially ca. 540-500 Ma, when new volcano-sedimentary assemblages ("pull-apart basins") and plutonic bodies (alkaline granites) were formed and emplaced. This geodynamic process was caused by the continuation of the oblique convergence of the northern domains, Hoggar-Potiguar and West Africa-Parnaiba against the Cariris Velhos orogenic zone, with the development of important thermal anomalies along the shear zones, (up to $700^{\circ} \mathrm{C}$ ) and slow events of cooling (from 580 to $500 \mathrm{Ma}$, Corsini et al., 1997).

d. The Southern Domain, to the south of the Pernambuco lineament is characterized by the evolution of the orogenic systems (derived from previous continental margins) of the northern peripheries of the São Francisco Craton. A systematic display since external zones (foreland, São Francisco Craton, to the south) to internal zones (hinterland, Pernambuco-Alagoas massif, other basement blocks of southeast Piaui, to the north) may be observed. These belts are composed by assemblages of passive continental margins (diamictite-quartzite-pelite-carbonate) which have gradually evolved to volcano-sedimentary and to deep-water sediments assemblages (to the north), with some local indications of oceanic realms and subduction zones near their hinterlands. Relicts of oceanic and/or island arcs realms have been pointed out in these distal zones of Riacho do Pontal belt (Monte Orebe unit) as well as in the far interior (Canindé unit) of the Sergipano Belt. The presence of some segments of Mesoproterozoic orogenic belts (Cariris Velhos or alike) in the backland zones (mostly Paleoproterozoic domains) has been indicated by preliminary isotopic data. Regarding the occurrences of basement rocks, of particular interest is the presence of litho-structural assemblages (with primary N-S trends, Archean and Paleoproterozoic in age) proceeding from the southern domains, from the São Francisco Craton basement, and then submitted to the newer (E-W) structural trends of the Brasiliano framework.

The installation of these continental margins presents indirect values of ages around $750 \mathrm{Ma}$. Age values about $630 \mathrm{Ma}$ have been inferred for the main phase of folding, with the late orogenic plutonism dated between 580 and $540 \mathrm{Ma}$.

To the more distal parts of the Sergipano belt and between this and the Pernambuco Lineament there occurs the granitic-migmatitic rocks of the Pernambuco-Alagoas Massif, a very particular geologic context, around $125,000 \mathrm{~km}^{2}$ in area, with several indications of preBrasiliano rocks, and the effects of the Brasiliano granitization are overspread. The eastern part of this massif presents many lithological remnants of Paleoproterozoic rock units, while its western part seems to have an important contribution of Mesoproterozoic granitic rocks (Cariris Velhos orogeny), with a small Archean nucleous.
Granitic rocks of magmatic-arc affinities occur in its southern border, cutting across the previous litho-structural rock units (Paleo and Mesoproterozoic).

The final evolutionary phase of the province, responsible for its last structural pattern-pre-Mesoproterozoic drift-was deeply marked by post-collisional extrusional movements, having the lineaments as preferential sites. With this escape tectonics some new volcano-sedimentary basins were emplaced as well as anorogenic plutons, fissural intrusives and hydrothermal veins, for which different geochronology methods have indicated ages between 540 and 500 Ma.

The structures of the Borborema Province have been recognized in the basement of the continental margin, where strong tectonic heritage has been identified in the general architecture of their basins. The correlation of the structures of the Borborema Province with those of northwest Africa (from Togo to Cameroon) has been subject of many previous studies, mostly under reconnaissance scales. To the interior of the South American continent, beneath the sediments of Parnaiba and Urucuia basins, geological links can be noticed between Rio Preto-Riacho Pontal belts and the Brasilia belt, of the Tocantins Province.

\section{Tocantins orogenic system}

The set of orogenic belts flanking the east margin of the AmazonasPampia plate (Figure 2) has been named as Tocantins Province (Almeida et al., 1981), but it is necessary to remark their different segments with different evolutionary histories: Araguai (northern branch, between Amazonas and West Africa-Parnaiba), Brasilia (central branch, also flanking the western border of the São Francisco plate), southeastern portion (between S. Francisco and Rio de La Plata plates) and the southwestern branch, Paraguay-Pampean (one of the youngest segments of the Brasiliano collage).

\section{Araguaia Belt}

The Araguaia belt is a NS-trending thrust-and-fold belt, about 1,000 $\mathrm{km}$ long and $100 \mathrm{~km}$ wide, covered to the east by the Parnaiba Basin. It is composed of metamorphosed psammitic and pelitic sequences, with minor carbonatic rocks and numerous mafic and ultramafic bodies assembled in the Baixo Araguaia Supergroup. The western and external domain is formed by the low-grade metasediments of the Tocantins Group, comprising mainly chlorite-muscovite schists, phyllites and quartzites (Pequizeiro Fm), and phyllites, slates, metaarkoses and metalimestones (Couto Magalhães Fm), the latter overthrusting or overlying (by unconformity) the basement of the Amazonas craton to the west. The eastern and internal domain is composed of micaschists (garnet, staurolite, kyanite) of the Morro do Campo Fm, feldspatic schists (Canto da Vazante Fm) and micaschists, calc-schists, marbles and amphibolites (Xambioá Fm), assembled as the Estrondo Group. This domain is marked by domelike structures cored by orthogneissic and migmatitic basement inliers of Archean and Paleoproterozoic ages.

Mafic and ultramafic rocks are associated with both the basement and supracrustals, mostly in the western domain, within the Tocantins Group. Serpentinized peridotites and dunites, with chromite pods (Koutschoubey and Hieronimus, 1996; Teixeira, 1996), are associated with chert and jaspilite. Additional occurrences of pillow basalts have been noticed, adding the notion that these bodies are remnants of ophiolitic complexes (like those of the Rockelide belt to the north, on the African side).

Ages of the supracrustal piles are not adequately constrained, but there are indirect evidences (rifting of the basement) for a Neoproterozoic age. Age of metamorphism is preliminarily defined by $\mathrm{Pb}-\mathrm{Pb}$ zircon data of $655 \pm 24 \mathrm{Ma}$ (Moura and Gaudette, 1993) to the emplacement of syntectonic granites.

Structural grain is defined by pervasive foliation and major thrust faults, generally NS-trending and with gentle dips to the east, 
as well as the mineral and stretching lineations. Structural analyses suggest westward crustal shortening and tectonic transport toward NW, indicating oblique collision. Metamorphism is of barrovian type, increasing from incipient (to the west) to middle-high amphibolite facies to the east. Superimposed NNE-SSW strike slip displacements of the Transbrasiliano Lineament reach the southern portions of the Araguaia Belt, and this is assumed as their limits with the Central Goiás and other supracrustals of the Brasilia Belt. The Ilha do Bananal Cenozoic sediments are hiding the possible links with the Paraguay belt to southwest.

\section{Brasília Belt}

The Brasilia Belt is a complex orogenic system (thin and thick-skin), $1100 \mathrm{~km}$ long, displaying structural vergence towards the São Francisco Craton, with $\mathrm{P}$ and $\mathrm{T}$ metamorphic conditions increasing progressively towards the west.

The basal stratigraphic succession, the rift sequence of the Arai Group (Statherian in age), is overlain by the Paranoá Group (ca. 1.0 $\mathrm{Ga}$ ), a mainly detrital sedimentary assemblage also including some carbonatic strata, which, together with the Vazante and Canastra groups (in the south), are interpreted as the shelf sequence of a typical passive margin (Fuck et al., 1993) outlining the western margin of the São Francisco-Congo continent. This sequence is overlain by paraconglomerates and carbonate-bearing phyllites of the Ibiá Group, which seem to be representing outer shelf and slope deposits.

The internal domain of the Brasilia Belt is mainly formed by the Araxá Group metasediments, micaschists and quartzites from deep waters environments of the continental slope and rise. Abundant amphibolites are associated with these sediments, some of them displaying chemical signatures of continental tholeiites, and many others presenting chemical and isotopic signatures of Neoproterozoic (Sm$\mathrm{Nd}$ whole rock isochron ca. $\left.1010 \pm 103 \mathrm{Ma}, \varepsilon_{\mathrm{Nd}}=+5.3\right)$ depleted mantle-derived oceanic crust ( Brod et al. 1991; Fischel et al., 1999). The structural overall pattern of the Araxá rock units is characterized by shallow-angle foliations and thrust sheets verging towards the São Francisco Craton, and E-W lineaments interpreted either as lateral ramps or secondary superposed thrust events. A distinctive feature for the Araxá Group is the occurrence of a series of small serpentinite bodies forming a ca. $200 \mathrm{~km}$ long ophiolitic mélange (Strieder and Nilson, 1992). The thrust sheets and the mélange suggest that Araxá rocks could correspond to an accretionary wedge thrust over platformal sequences of the passive margin.

The pelitic-carbonatic sequence of the Bambuí Group (with a basal diamictite) overlies the passive margin sequence and also large areas of the São Francisco Craton, where it is a flat-lying cover almost without deformation. Some authors, e. g., Thomaz Filho et al. (1996) have suggested that the Bambui Group (or the youngest part of it) was formed in response to the development of the Araxá thrust sheets in the west.

Recent Sm-Nd data shed some light (Pimentel et al., 1999a) to the source areas of the sediments. Only Paleoproterozoic source areas (probably from rocks of the former São Francisco continent) were involved in the deposition of the Paranoá, Vazante and Canastra groups. Araxá and Ibiá samples have shown bimodal model ages, with a group of data between 1.5 and $1.0 \mathrm{Ga}$ (derived from Neoproterozoic Magmatic arc, to the west?) and other different groups with data between 2.3 and $1.8 \mathrm{Ga}$. Model ages between 1.4 and $1.9 \mathrm{Ga}$ for the Bambui sediments are somehow compatible with the model of a foreland basin model.

Another feature worthy of mention in the internal domain is the high grade rocks of the Anápolis-Itauçu Complex, a NW-SE elongated zone (250 km long, $70 \mathrm{~km}$ wide), exposed west of the Araxá Group sediments by high angle mylonitic zones. Many different rock types are present there, including orthogranulites, mafic-ultramafic rocks, aluminous granulites, garnet-gneisses, minor marbles, calc-silicatic rocks, quartzites, as well as a large number of granitoids intrusions, with poorly known chronostratigraphic relationships due to the complex deformational patterns. Recent Sm-Nd model ages (Sato, 1998; Fischel et al., 1998) point out the range
1-1.3 Ga, interpreted as the approximate upper age limits for the protoliths of the granulitic rocks (Pimentel et al., 1999c). The highgrade metamorphic event has been defined as of late Neoproterozoic in age, ca. 630-610 Ma (Fischel et al., 1998).

Some granite intrusions are present in the internal domain, either within the Araxá or the Anápolis-Ituaçu assemblages, but without reliable geochronological data. There is one exception for the Maratá subvolcanic granite, which has an U-Pb zircon age of 794 $\pm 10 \mathrm{Ma}$ (Pimentel et al., 1992). Preliminary Sm-Nd data for these granites display a range of ages similar (1.8 to $1.5 \mathrm{Ga})$ to those of the Araxa and of the granulitic complex, suggesting that they could be derived from remelting of crustal materials during the Neoproterozoic.

To the west of that internal zones there are the expositions of the Central Goiás Massif, a very complex crustal fragment (hinterland), including Archean granite-greenstone assemblages, Paleoproterozoic orthogneisses and volcano-sedimentary sequences, overlain by the Serra da Mesa Group (a clastic assemblage). Its eastern limit is marked by the layered mafic-ultramafic complexes of Barro Alto, Niquelândia and Cana Brava. The crystallization ages for these complexes are around 2.0 Ga (Correia et al., 1997, among others), and the high-grade metamorphism was dated at ca. 780 Ma (Ferreira Filho et al., 1994).

The western area of the Brasilia Belt comprises large exposures of the Goiás magmatic arc (in Mara Rosa Terrane). Most of the arc magmatism is represented by metaplutonic rocks, tonalites and granodiorites, exposed between narrow belts of neoproterozoic volcano-sedimentary sequences. The oldest rocks are orthogneisses dated at ca. 0.93-0.90 Ga and the Mara Rosa tonalite dated at ca. $0.86 \mathrm{Ga}$ (Pimentel et al., 1997). In the Iporá-Jaupaci area, the arc magmatism is much younger, with orthogneisses (arc types) being dated between 0.73 and $0.64 \mathrm{Ga}$ and arc metarhyolites with $\mathrm{U}-\mathrm{Pb}$ zircon ages between 0.76 and $0.64 \mathrm{Ga}$ (Pimentel et al., 1999 a). Geochemical data show that these younger rocks are the much more evolved types, in contrast to the older arc rocks which have very primitive signatures, being similar to mantle-derived granitoids of young intra-oceanic island arcs.

\section{Southernmost portion}

This portion comprises a flat-lying package of east-northeastwarddisplaced nappes (Figure 4), representing a diachronic thick-skinned and frontal growing nappe system that underwent a minimum of 300 $\mathrm{km}$ in magnitude of aggregate displacement, accounting for deeper crustal levels progressively exposed in the western allochthons. The uppermost tectonic unit derived from magmatic arc terrane (Socorro-Guaxupé) displays high-pressure and high-temperature basal granulites. High-pressure terrane is underlain by the Ky-granulite sheet (Três Pontas-Varginha nappe) and the metapelite-metagreywacke flake (Carmo da Cachoeira and Aiuruoca-Andrelândia nappes). The lower allochthonous units are made up of mediumpressure metamorphic sequence associated with polymetamorphic orthogneisses (Luminárias-Carrancas and Lima Duarte nappes) which grade, in a trailing imbricated fan type thrusts, to the parautochthonous units (Campos Neto and Caby, 1999a).

The Socorro-Guaxupé terrane is a giant allochthon showing a right-way-up crustal section of hot and partially melted layered crust. It comprises basal banded enderbite partially derived from a Neoproterozoic nearly juvenile immature magmatic arc setting ( $\mathrm{Sm}$ $\mathrm{Nd} \mathrm{T}$ DM model ages ca. $1.3 \mathrm{Ga}$ ). These granulites grades upward into a predominant grey to pink, metaluminous migmatites with (to their top) pelitic to semi-pelitic migmatites. From these migmatites longitudinal right-hand strike-slip shear zones control a major metamorphic jump (southwestwards) to greenschist facies. Various syn-orogenic deformed plutonic rocks having mainly $0.63 \mathrm{Ga}$ (between $0.67-0.625 \mathrm{Ga}$ ) show chemical and isotopic signatures compatible with the evolution of a subduction-related magmatism onto continental setting and contain systematically Mesoproterozoic Sm-Nd $\mathrm{T}_{\mathrm{DM}}$ values. They are of a porphyritic, jotunitic-charnockitic suite, that gives way upward to a mangeritic suite and, at higher levels, to 


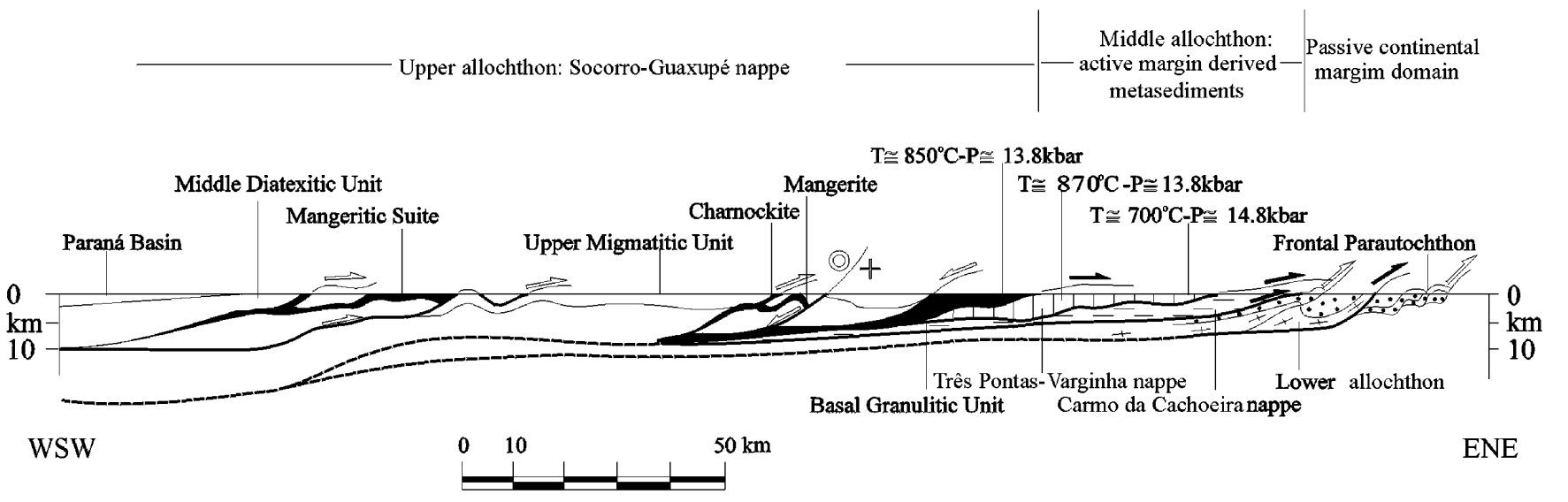

\section{Figure 4 Tectonic profile through the southern Tocantins orogenic system.}

batholiths of porphyritic granitoids. The base of the nappe underwent $T=750-870^{\circ} \mathrm{C}$ and $P=11.5-14.0$ kbar of metamorphic conditions, and yield an isobaric heating evolution toward $860-920^{\circ} \mathrm{C}$, consistent with dry melting and generation of anhydrous charnockitic-mangeritic magmas. The upper migmatites underwent low-pressure metamorphic conditions $\left(T=820^{\circ} \mathrm{C}\right.$ and $\left.P=4.5 \mathrm{kbar}\right)$. $\mathrm{Sm}-\mathrm{Nd}$ data point out (cooling around $600^{\circ} \mathrm{C}$ ) ages for this metamorphic path occur at $0.63 \mathrm{Ga}$, when major syn-metamorphic detachment, locally accommodated by a NW-oriented oblique lefthand strike-slip fault, accounts for the direct contact of the uppermost migmatitic unit above the basal granulites (Campos Neto and Caby, 1999b). The late metamorphic NE-displaced out-of-sequence thrusts are younger than the $0.625 \mathrm{Ga}$ mangerites. Post-kinematic intrusion of potassic syenites are present (ca. $0.61 \mathrm{Ga}$ ), starting the inner post-collision extensional environment.

The Três Pontas-Varginha nappe is a thick sheet that crops out for $170 \mathrm{~km}$ parallel to its ENE displacement direction. The nappe package comprises mainly coarse-grained Rut-Ky-Grt granulites, lesser impure quartzites, and few calc-silicate rocks, gondites, lenses of metabasic rocks and rare sills of mafic-ultramafic rocks. Upward the Ky assemblage gives way to sill-bearing granulites up to migmatites. The Aiuruoca-Andrelândia and Carmo da Cachoeira nappes bellow are chiefly made up of a layered sequence of peraluminous Rut-Ky-Grt-Ms schists and dark-grey, massive Grt-Bt-Pl gneisses and schists. Small lenses of metabasic rocks rise to eclogitic metamorphic assemblage. The chemical and isotopic characteristics of these rocks are correlate with the Ky-granulites described above. The former have a pelitic source showing $\mathrm{Sm} / \mathrm{Nd} \mathrm{T}_{\mathrm{DM}}$ and $\mathrm{U}-\mathrm{Pb}$ ages (on detritical zircons) ca. $1.9 \mathrm{Ga}$ (Söllner and Trouw, 1997). The latter has a graywacke chemistry with $\mathrm{T}_{\mathrm{DM}}$ model ages between 1.16 and $1.55 \mathrm{Ga}$, becoming to unravel their Neoproterozoic juvenile volcanic arc source.

A coherent inverted metamorphic pattern is supported by these nappes. Lower temperatures $\left(650^{\circ} \mathrm{C}\right)$ were attained under high-pressures (12-14 kbar) related to the decompression stage of eclogite conditions $\left(660^{\circ} \mathrm{C}-17.5\right)$. Upward the temperature increase to $700^{\circ} \mathrm{C}$ $(P=15 \mathrm{kbar})$ on $\mathrm{Ky}$-granulites to get $830-950^{\circ} \mathrm{C}$ in a near-isobaric heating path. The syn-kinematics decompression related to the outof-sequence thrusting varies from $600-690^{\circ} \mathrm{C}$ and $9-11 \mathrm{kbar}$ at ca. $610 \mathrm{Ma}$ (Campos Neto and Caby, 1999b) accomplishing, in $20 \mathrm{Ma}$, the short-lived syn-collision metamorphic evolution.

The psammitic rock associations that are related to the passive continental margin deposits occur as the lower allochthon and parautochthonous units, where the major sheet shows eastward minimum transport of $140 \mathrm{~km}$. They are composed mainly of white and green mica quartzites grading upward into well-bedded to laminated quartzite interlayered with graphitic and aluminous metapelites (Ribeiro et al., 1995). Polymetamorphic orthogneisses and migmatites also belong to the nappe package, and a Barrovian-type mineral succession is described (Trouw et al., 1986). Eastward, the later and external thin-skinned $\mathrm{N}$-directed thrusting pattern predominates (duplex under the scale of kilometer)

In brief, the southern extension of the Tocantins orogenic system represents the collisional juxtaposition of 3 major tectonic settings: 1 - A southwestern long-lived Neoproterozoic immature to mature Socorro-Guaxupé magmatic arc terrane, which displays a tight paleogeotherms pattern. This process may be supported by double subduction: one NE-dipping from Rio de la Plata plate, and other SW-dipping from Anápolis-Andrelândia terrane; 2 - A metasedimentary assemblage with contributions from an active margin environment from the Anápolis-Andrelândia terrane. The high-pressure metamorphism implies a low paleothermal gradient which could be achieved in an ocean closure through a SW-dipping subduction, at least $60 \pm 5 \mathrm{~km}$ deep; 3 - Passive continental margin assemblages (lower allocthon and parautochthonous units).

The inverted metamorphic field gradient is shown by diachronic mineral equilibration at different temperatures throughout the metamorphic prism. It requires the rapid emplacement of the upper hot allochthon resulted from the main frontal collision of the Rio de la Plata plate against the São Francisco plate at $0.63 \mathrm{Ga}$. The magmatic arcs were upward exhumed and thinned from the deeply subducted slab and driven horizontally above the edge of the São Francisco plate by fast continental subduction process after complete resorbtion of the oceanic domain. The hinterland-driven syn-metamorphic detachment could be the result from internal extension by dynamic compensation in response to the possible building of an Himalayan size mountain range.

\section{Paraguay Belt}

The Paraguay Belt and its corresponding cratonic cover were deposited on the southeastern margin of the Amazonas-Pampia Plate, this including the orthogonal branch of the Tucavaca Belt (extending westwards into Bolivia). The sedimentation of the supracrustal sequences has started in the Vendian (610-570 Ma ago, Trompette, 1994) with the deposition of glaciogenic (rift-related) and turbiditic rocks of the Puga and Cuiabá formations. A carbonatic rock unit - Araras Fm - is overlying and marking the end of the glacial features in the whole basin. The two basal units may be traced for long distances along the margin of the craton as well as inside the Tucavaca rift (where they are known as Boqui and Murcielago groups).

In Corumbá area, the southern part of this belt, the basal unit includes large manganese and iron deposits (Jacadigo Group) followed by carbonate deposits of the Corumbá Formation (an equivalent of Araras). The Corumbá group is up to $700 \mathrm{~m}$ thick (Boggiani, 1997) and comprises conglomerates, sandstones and pelites at the 
base, which pass into shallow-water dolostones, and then (to the inner part of the basin) to lime-rich mudstones.

The uppermost limestones (near Corumbá) of the sequence contain remains of Ediacaran-like metazoans and metaphytes, as well as other microfossils (Zaine and Fairchild, 1985), indicating Vendian age for the deposition of these rocks.

The upper part of the sedimentary succession consists of siliciclastic rocks, cross-bedded sandstones (Raizama Fm), followed by red shales, siltistones and arkoses (Diamantino Fm) assembled in the Alto Paraguay Group. Some shales of this sequence have yielded a $\mathrm{Rb}$-Sr isochronic age of $568 \pm 20 \mathrm{Ma}$, interpreted as age for diagenesis (Cordani et al., 1985).

The dominant deformational style of the belt is marked by steeply dipping planar structures, and a generally fan-like distribution of axial-plane foliations is observed. Although increasing from west (the craton) to the east (hinterlands, Mara Rosa and Central Goiás terranes), metamorphism and deformations are weak, suggesting moderate horizontal shortening. Apparently, the Brazilian part of this belt had an ensialic evolution, as indicated by the sedimentological features and the lack of volcanism and other characteristics (as recorded to the south, in the Pampean area, assumed as probable continuation) of oceanic realms.

Rocks of the Cuiabá Group were intruded by post-orogenic granites, like the São Vicente (east of Cuiabá), for which there is a previous Rb-Sr isochronic age of ca. $508 \mathrm{Ma}$ (Almeida and Mantovani, 1975).

Available geochronological and paleontological data indicate late Neoproterozoic-Cambrian phases of sedimentation, followed by closing and inversion (collisional) of the basin between 550-500 Ma (Trompette, 1994), but this need to be redefined.

\section{Pampean (Paraguay) Orogen}

The Pampean Province (Ramos, 1988) in Argentina is the central southwestern part of the Brasiliano mosaic of the basement of the South American platform, being characterized as an orogenic development of the lower and middle part of the Cambrian Period. Their analyses and studies have been difficult and puzzling due to the structural overprint of the subsequent orogenies of the Phanerozoic tectonic cycles (Famatinian, Hercynian and Andean), as well as to the many Phanerozoic cover rocks of the Chaco-Paraná Basin and from the Pampas plains.

This province shows presently north-south structures as a result of interaction convergent processes between the blocks of ArequipaAntofalla (Paleoproterozoic and Mesoproterozoic segments, to the west), Pampia (central, a Mesoproterozoic-Grenvillian block) and Rio de La Plata (or a partial agglutination of Pre-Gondwana blocks) that gave birth to the fold belts of Puncoviscan (West Pampean) and Cordoban (Eastern Pampean). Like the Paraguay belt (their natural continuation to the north) this evolution began with the Varengian taphrogenesis (610-590 Ma, Knoll and Walter, 1992) at the same type of the glacial sedimentation of Puga formation and associated assemblages of rift environments.

The Puncoviscan belt has evolved from an wide continental margin and displays richness and variety of lithological facies from continental to marine environments and a remarkable contingent of fossils from the Vendian to the Lower Cambrian (Rapela et al., 1998). The subsequent process of subduction was developed from west to east, under the Pampia microplate, leading to a collisional process between this microplate and the Arequipa Antofalla block, still in Cambrian times. Undeformed rocks of the Upper Cambrian age are covering a complex pattern of isoclinal folding of this Puncoviscan belt.

The Serra de Cordoba (Eastern Pampean) displays a predominance of paragneisses and aluminous schists, migmatites and aluminous granites, which, according to their PTt patterns, represent the litho-structural records of a collisional orogen (with a short or disputable history of subduction). This collision was developed between the Pampia microplate (with the magmatic arc developed by the Cambrian subduction of the Puncoviscan ocean) and the Rio de La Plata plate (or the previously agglutinated continental landmass, to the east of Gondwana). The geochronological data for these processes are well constrained in the span of 533-519 Ma (Rapela et al., 1998), coeval of those processes of the Puncoviscan belt.

As previously mentioned, this Pampean area seems to be the natural continuation of the Paraguay belt, partially hidden by the Cenozoic Chaco sediments. So considering, this area is only a local outcropping feature, the youngest one, of the tectonic cycle of the Rokellides-Goianides-Puncoviscan ocean, where the development reached the early Cambrian. To the southern part of the Gondwana continent, the structural continuation of these orogenic systemsTerra Australis (Cawood et Leitch 1998) - the collisional processes were still younger, between 510 and $490 \mathrm{Ma}$, i.e., reaching the Tremadocian age (Lower Ordovician). Therefore, the last and youngest orogenic stages of the Brasliano/Pan African collage were coeval with Ordovician marine invasions that were then occurring in the northern part of the just-agglutinated Gondwana supercontinent, where stable shelf conditions had already been established.

During the subsequent geologic period, firstly in the Ordovician and Lower Silurian times, this part of the province was deeply affected (deformation, metamorphism, plutonism) by the development of the Famatinian orogenic cycle, i.e., the history of birth and subduction of the Iapetus Ocean (southern branch). Besides, both the Hercynian (Permian and Triassic) and Andean orogenic events used to reach and reactivate (even in the Tertiary period) the whole Pampean orogenic systems.

\section{Mantiqueira branched system of orogens}

The geological scenario of the south-southeastern Atlantic coastal area of Brazil and Uruguay (also including in the interior of the continent the parallel range of Mantiqueira) is a NE-trending orogenic system, mostly controlled by (late) steep strike-slip shear zones. It comprises a series of terranes that have diachronically collided against the just-amalgamated (0.63-0.62 Ga) São Francisco-Rio de La Plata plates, forming the orogenic system that is the final result of the cyclic history of the Adamastor Ocean on this South American side. Such history is relatively well-constrained on the African side by Stanistreet et al. (1991) and Frimmel et al. (1998), where a initial $(0.76-0.70 \mathrm{Ga})$ and a final $(0.61-0.55 \mathrm{Ga})$ glacial stages are enveloping the well-sorted stratigraphic pile, which display the major lithological records of marine transgression and of the development of a passive continental margin.

On this South American side, the onset of the passive continental margin and associated glacial deposits (Sturtian age) is recorded in the eastern edge of the São Francisco plate (MacaúbasJequitaígroup). Other equivalent glacial deposits occur as a flat-lying cover of the whole São Francisco plate.

Five narrow and elongated (Figure 5) small plate fragments (descendants of Rodinia) played an important role in the history of this orogenic system. Two of them present previous Mesoproterozoic volcanic-sedimentary sequences overlaid by passive continental margins deposits, with either pelitic-carbonatic assemblages (Apiaî terrane) or terrigenous rock-units (Luis Alves terrane) predominating. The basement of Apiaí terrane is gneissic-migmatitic, Paleoproterozoic in age, while the basement of Luis Alves terrane is characterized by a poly-orogenic Archean-Paleoproterozoic granulitic complex, somehow preserved of Brasiliano deformation (Basei et al., 1998). The other three terranes - Curitiba, Juiz de Fora and Serra do Mar - present a polymetamorphic Paleoproterozoic basements overlaid by volcano-sedimentary sequences (Juiz de Fora and Serra do Mar) and sequences of metacarbonate-metapelitic-psammitic (Curitiba) nature, for which the ages are still uncertain. These sequences may be derived respectively from Neoproterozoic arc systems and passive continental margins. Only those of the Serra do Mar terrane have some isotopic data pointing out a Neoproterozoic 


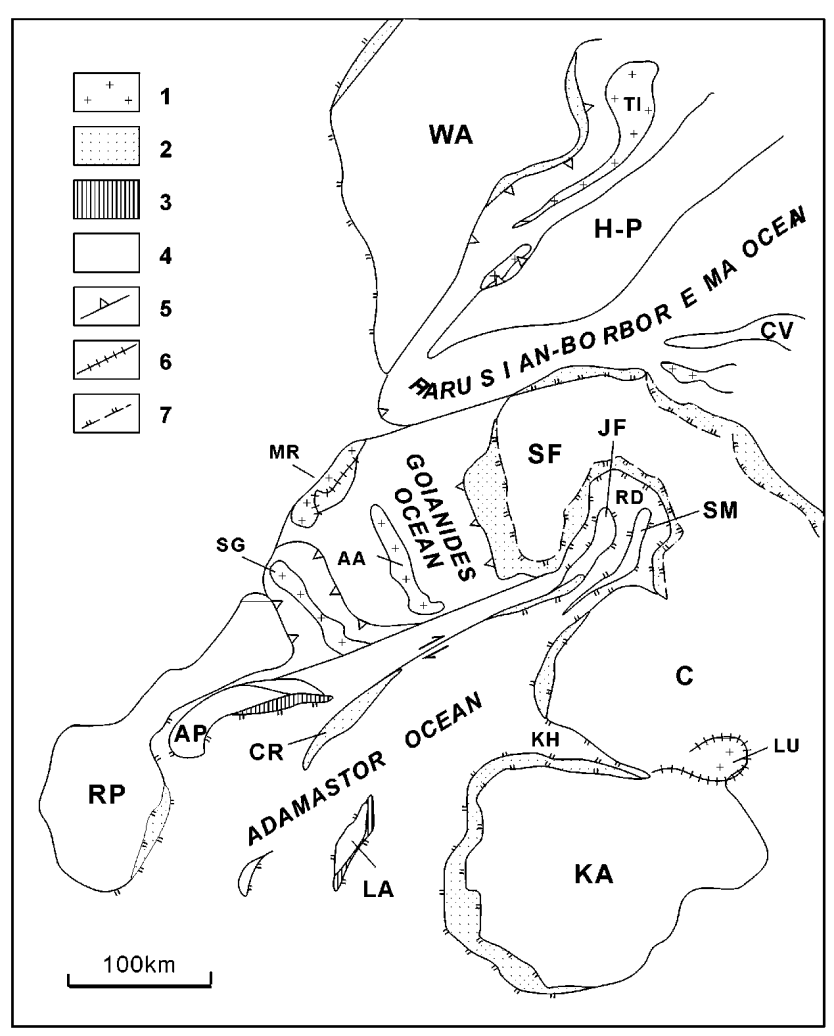

Figure 5 Vestiges of the lost oceans from Rodinia to Western Gondwana: ca. 750-700 Ma paleogeographic outline. 1. Tonian/Cryogenian magmatic arcs; 2. Passive continental margin deposits and thinner continental crust domains; 3. Mesoproterozoic belts; 4. Continental plate segments; 5. Subduction zones with the sense of dip; 6. Cryogenian sutures, 7. Ancient rift lines. AA - Anápolis-Andrelândia; AP - Apiaí; C - Congo; CG - Central Goiás terrane; CR - Curitiba; CV-Cariris Velhos; H-P - Hoggar-Potiguar; JF - Juiz de Fora; KA -- Kalahari; KH - Khomas gulf, LA - Luis Alves; LU - Lufilian; MR - Mara Rosa; RD - Rio Doce gulf; RP - Rio de la Plata; SG - Socorro Guaxupé; SF - São Francisco; SM - Serra do Mar; TI - Tilemsi; WA - West Africa.

juvenile sources. Besides all that, there is a small anonymous fragment/terrane composed of migmatites with a Kibaran age of metamorphism (Precciosi et al., 1999) that has preliminarily been identified in southeast Uruguay, to the east of the Pelotas arc.

The first well-constrained plate interaction for this orogenic system was ca. $0.705 \mathrm{Ga}$, with the formation of the intra-oceanic Rio Vacacaí arc (Babinski et al. 1996) in Rio Grande do Sul. The main and subsequent phase of plate convergence took place southwestward, with the development of the Pelotas magmatic arc, facing the eastern part of the Luis Alves terrane. This arc comprises a series of calc-alkaline plutonic rocks and high-K porphyritic granites (0.63-0.61 Ga), displaying flat-lying foliations related to strong deformation caused by W-NW tectonic transport (Fragoso Cesa and Machado, 1997; Silva et al., 1998). Late intrusion of aluminous granites related with strike-slip displacements, and some post-collisional pink granites $(0.594 \mathrm{Ga})$ also occur. At the same time (ca. $0.615 \mathrm{Ga}$ ), the Pien magmatic arc was being accreted (Harara et al., 1997) in the eastern part of the Curitiba terrane, as a result of a westward process of subduction.

The main collisional orogenic interaction - Mantiqueira orogen, ca. $0.6 \mathrm{Ga}$ - was responsible by the juxtaposition of Pelotas arc, Luis Alves terrane, etc. and the southeastern part of Rio de La Plata plate, with the closure of all oceanic spaces between that major arc and the Apiaí terrane. Undeformed successor volcano-sedimentary basins were subsequently developed (Luis Alves and Curitiba terranes mostly), with roughly N-S trends, and they are characterized by fluvial and lacustrine deposits and alkaline-peralkaline granitic intrusions (0.6-0.57 Ga), according to Siga Jr. et al. (1999). These basins may represent the result of impactogenic processes.

Remnants of marine deposits are related with the development of the foreland basin (south of Luis Alves block) of Itajaí and Camagua, which were pierced by intrusive granites and volcanic felsites $(0.56 \mathrm{Ga})$. These deposits contain several Vendian species of palynomorphs, and their stratigraphic history is between $0.59 \mathrm{Ga}$ (basal volcanism) and $0.53 \mathrm{Ga}$ (age of the thin-skin deformation).

A extension to the north of the Adamastor ocean is recognized and it is here called the Rio Doce gulf, which is admitted to be also formed around $0.75 \mathrm{Ga}$, based on data of amphibolitic rocks (Pedrosa-Soares et al., 1998). The first record of subduction-related, juvenile, partially intraoceanic, calc-alkaline volcano-plutonic arc is recognized eastward of Juiz de Fora terrane: the Rio Negro magmatic arc, at ca. $0.63 \mathrm{Ga}$ (Tupinambá, 1999), which was lately accreted on the Serra do Mar terrane. A juxtaposition of the arc and the Juiz de Fora terrane took place at ca. $0.6 \mathrm{Ga}$ in an oblique way, and so, to the north, a continuation of the eastward subduction was possible.

The main oceanic plate convergence took place at the same time, around $0.60-0.58$, forming the Galileia plutonic arc, which displays strong crustal contribution (Nalini et al., 1998), as a product of an east-dipping subduction from the eastern passive continental margin of the São Francisco plate, and that was accreted to the Juiz de Fora terrane. Remnants of oceanic convergence and subduction have positioned the Juiz de Fora terrane above the Serra do Mar microplate at about $0.59-0.57 \mathrm{Ga}$, forming the plutono-migmatitic root of the Rio Doce magmatic arc (after Campos Neto and Figueiredo, 1995 and Wiedmann et al., 1997).

As accretionary episodes, the collisions were also diachronically younger towards the east. The Araçuaí belt (eastern edge of the São Francisco plate) is related to the collision of the Juiz de Fora terrane against the São Francisco plate and it presents a series of westward displaced thrusts under medium pressure metamorphic conditions. A main suture zone is related to the 0.58 Ga Abre Campo crustal discontinuity described by Fischel et al. (1998).

A widespread series of syn-kinematics $(0.57-0.55 \mathrm{Ga})$ peraluminous diatexites, and I-type granites and mangerites occur in the Serra do Mar terrane. They are related to the final closure of the Vshape oceanic remnant between Serra do Mar and Juiz de Fora landmasses.

The continuation of the predominating westward compression has caused a steep-dipping shear belt, a long and linear site for extrusional displacements that is positioned along the central part of this northern portion of the orogenic system. The "Além-Paraiba" shear zone, up to $100 \mathrm{~km}$ wide, is associated with high grade metamorphism and granitic plutonism (0.58-0.55 Ga, Machado et al., 1996, Ebert et al., 1996). A series of pull-apart basins occur along this huge system of strike-slip faults, and they were weakly deformed by transpression and metamorphosed under very low grades.

Mantle- and crust-derived magmas mixing-mingling is observed along a newer post-collisional arc (ca. 0.52-0.51 Ga, Wiedmann et al., 1993) accreted mainly in the Serra do Mar terrane. It could be connected with the maintenance of the high-thermal gradient inducing metamorphism up to Earlier Ordovician times. Otherwise it could be related to a late (far-away) west-dipping subduction process, somehow connected with the final closure of the eastern Adamastor Ocean $(0.54-0.53 \mathrm{Ga})$ inducing the east-verging deformation, observed in the foreland deposits of the African side.

\section{Geodynamic evolution}

The up-to-date paleomagnetic-supported reconstruction of Rodinia (Figure 1) shows a Panthalassan-size ocean (Monrovia) in the remaining Earth's surface (Weil et al., 1998). The large ArabianNubian Ocean (Stern, 1994), west of the Congo plate, and the probable South Pole connection with the (frozen) Pharusian Ocean 
(Caby, 1994), on the western side of the West Africa plate (Figure 1 ), were remarkable pieces of that oceanic realm. The Goianides and the Borborema Pharusian oceanic realms could have then had frank connections.

Additionally, extensional regimes $(1.1-0.97 \mathrm{Ga})$ have immediately followed the development of the Grenville orogeny in the Amazonas plate (Bettencourt et al., 1999), as well as the Cariris Velhos orogeny in Borborema. Coeval mafic dike-swarm have occurred in the São Francisco plate (ca. 906 Ma, Machado and Noce, 1993). All these data are recording the onset of the broad taphrogeny of the Tonian period, a first trigger for the later Rodinia break-up. A probable rift-drift psamitic-dominated sequence related to that taphrogenic episode seems to be preserved on the western border of the São Francisco plate (the Paranoá and Canastra Groups). The Rio de la Plata continent was rifted-away from the western Kalahari and submitted to a northeastward drift. Small fragment containing Grenvillian rocks (Correia et al., 1999) was separated from Amazonas plate at that time (Central Goiás terrane).

While taphrogenic events were prevailing elsewhere, the Goianides oceanic plate started to face an east-dipping subduction since Late Tonian times $(0.90-0.85 \mathrm{Ga})$ that led to the accretion of the intra-oceanic island arc (Mara Rosa), which was later on docked to the continental fragment of Central Goiás Massif about $0.79 \mathrm{Ga}$ (after Pimentel et al., 1997). Other evolutionary arc systems (e.g. the Lufilian in Zambezi), microcollisions and dockage processes were elsewhere coeval (Porada, 1989). A roughly eastwards plate kinematics have led the Rio de la Plata continental block against the western part of the São Francisco plate, resulting in a long-lived oceanic plate convergence process. Similar kinematics drove the West Africa plate against the Hoggar-Potiguar terrane/plate in order to close the western branch of the Pharusian Ocean. At that time the former Transbrasiliano trace acted as a transform zone. A first magmatic arc, ca. $0.725 \mathrm{Ga}$, was formed (Figure 4), whereas on the western side of the West Africa plate it was still being submitted to taphrogenic episodes (Dallmeyer and Lécorché, 1989).

The above-mentioned phases of convergence are related to the global break-up of Rodinia and dispersion of their descendants, that commenced at ca. $0.75 \mathrm{Ga}$, including the separation of East Gondwana from the western margin of Laurentia (Park, 1994). Accordingly (and differently of the orogenic conditions of the Goianides and Pharusian oceanic realms), in the São Francisco-Congo plate taphrogenic processes were predominating during the middle part of the Cryogenian period. The Sturtian glacial deposits were widespread and were related to the main rifting stage in the Congo and Kalahari plates. They are well recorded in eastern (MacaubasJequitaí groups), southern (Bom Despacho), and northern (Bebedouro, Capitão-Palestina Fms) margins of the São Francisco plate; and were succeeded by passive continental margin settings and rock assemblages related to the opening of the Adamastor and southern Pharusian oceans (Figures 2, 3) and other connected realms. The Sturtian glaciogenic deposits are overlying by unconformity of the former passive continental margin assemblages of the Paranoá Gr in the western São Francisco plate. The post-glacial marine cap dolomites have covered the São Francisco plate, and they are associated with thick deposits of the passive continental margins, like the Vazante Fm at the west (Brasilia belt) and also to the north and northeast (São Desidério, Salitre and Olhos d'Àgua Fms) of this plate, in the interior of the southern domains of the Borborema province.

This extensional regime of mid-Neoproterozoic times was diachronically interrupted and reversed. The closure of Goianides, Pharusian and partially of the Borborema oceans took place ca. 0.63-0.60 Ga, respectively by frontal collision between Rio de la Plata and São Francisco plates, and between West Africa and Hoggar-Potiguar plates. It seems that the Três Marias foreland deposits upon the western São Francisco cratonic area could be related to this main collisional orogenesis. So, a span of life for the Goianides Ocean may be estimated in the range of $270 \mathrm{Ma}$.

The central-eastern part of the Tocantins orogenic system (product of that Goianides closure) has involved deep reworking of old continental crust, high-pressure overthrusting with crustal thickening and indentation processes, having as modern analogous the India-Asia collision.

Opposite to that, the western side of Adamastor ocean was populated by several microplates (already mentioned) which had diachronically collided against the just-assembled São FranciscoRio de la Plata plate. These processes are related to the building of the Mantiqueira branching system of orogens, that displays many intra-oceanic juvenile accretionary components of different ranges of time, with mean accretionary events between 0.6 and $0.57 \mathrm{Ga}$. East-dipping subductions have faced the remained passive continental margin of São Francisco plate (Galiléia arc), the western edge of the Juiz de Fora microplate (Rio Doce arc), and the NW dipping subduction of the western edge of the Luis Alves microplate (Piẽn arc). Around $0.575 \mathrm{Ga}$, the west-dipping subduction seems to have been responsible by the major oceanic crust consumption (Figure 5), related to the onset of the plate convergence process at the African side of the Adamastor Ocean, with collisional phases reaching 0.54 Ga (Khomas-Gariep-Saldania belts). Successor basins, anorogenic plutonism, escape-tectonics events, long-lived thermal anomalies, etc. have already been described in the last part of the evolutionary history of the Adamastor Ocean, with the final closure around 0.53 $\mathrm{Ga}$ (foreland deposits of the fish River Fm of Nama Basin) on the African side. Thus, the estimated life span of the Adamastor Ocean is ca. $220 \mathrm{Ma}(750-530 \mathrm{Ma})$, and these complex main characteristics of the Mantiqueira orogenic system - final product of the Adamastor closure - make it compatible with the Cordilleran-type.

During the late Neoproterozoic and Cambrian deep withinplate extrusional processes were also important in Borborema province. This was probably related to the continuity of the convergence processes of the interacting blocks (W-Africa, HoggarPotiguar, São Francisco plates). On the other hand, Vendian-age extensional basins (Itajaí, Camaquã, etc.) were formed in the eastern part of the Mantiqueira, and have barely been deformed in Early Cambrian times with the final adjustments of the Adamastor closure. Other undeformed volcano-sedimentary basins were also formed in the interior of the just-amalgamated plates in Early-Cambrian, due to different processes of post-collisional adjustments.

At that time of collisional and post-collisional adjustments, the eastern part of the previous Amazonas-Pampia plate was being rifted. The Varangian glacial deposits of the Puga Formation (Paraguay belt) were related to the fast rift-drift sedimentary assemblages then developed. A well-developed oceanic circulation permitted the explosion of the Cloudina and Ediacara faunas in the justformed Vendian-Early Cambrian passive continental margin. An east-dipping subduction at ca. 530 Ma started the PampeanoParaguay orogenic belt. This epilogue of the evolution of Western Gondwana was finished at ca. $520 \mathrm{Ma}$, with the subsequent collision of those fragments of the Amazonia-Pampia plate (namely Arequipa Antofalla and Pampia) and the Rio da Plata-São Francisco plate.

In brief, the Brasiliano-Pan African orogenic collage resulted from diachronic interactions among five major continental plates. Three sequential phases of rifting processes evolved towards wellconstrained passive continental margins and oceanic lithosphere development. At each plate divergent process, plate convergence led to the closure of the former ocean elsewhere. Different histories, paleogeographic features and life spans may be drawn for the oceanic realms, from one place to another. For instance, a span of life of at least $230 \mathrm{Ma}$ is inferred to the Tocantins orogenic system in opposition to a life span of about $13 \mathrm{Ma}$ that was recorded to the Pampean-Paraguay orogen. The evolutionary characteristics of the orogenic systems are different as there were their previous oceanic realms, from one case (Goianides/Hymalaian) to another (Mantiqueira/Cordilleran), and the steps of closure, formation of magmatic arcs, and collisional belts are marked by diachronism which implies space and time migration of the orogenic process. 


\section{References}

Almeida, F.F.M. and Hasui, Y., (coord), 1984, O Pré-Cambriano do Brasil: Edgard Blücher Editora, S. Paulo, 378 p.

Almeida, F.F.M. and Mantovani, M.S.M., 1975, Geologia e geocronologia do granito de São vicente, Mato Grosso: Anais da Academia Brasileira de Ciências, 47: 451-458.

Almeida, F.F.M., Hasui, Y., Brito Neves, B.B., and Fuck, R.A, 1981, Brazilian Structural Provinces: An Introduction: Eart-Science Reviews, 17:129.

Babinski, M., Chemale Jr., F., Hartmann, L.A., Van Schmus, W.R., and Silva, L.C., 1996, Juvenile accretion at 750-700 Ma in southern Brazil: Geology, 24: 439-442.

Babinski, M., Chemale Jr.F., Van Schmus, W.R., Hartmann, L.A., and Silva, L.C., 1997, U-Pb and Sm-Nd geochronology of the Neoproterozoic granitic-gneissic Dom Feliciano belt, Southern Brazil: Journal of South American Earth Sciences, 10: 263-274.

Bahlburg, H. and Hervé, F., 1997, Geodynamic evolution and tectonostratigraphic terranes of northwestern Argentina and northern Chile: GSA Bulletin, 109 (7): 869-884

Basei, M.A.S., Citroni, S.B.V., and Siga, Jr.O., 1997a, Stratigraphy and age of Fini-Proterozoic basins of Paraná and Santa Catarina States, Southern Brazil.

Basei, M.A.S., Siga, Jr.O., Reis Neto, J.M., Harara, O.M., Passarelli, C.R.and Machiavelli, A., 1997b, Geochronological map of the Precambrian terrains of Paraná and Santa Catarina, southern Brazil: tectonic implications.in 1th South American Symposium on Isotope Geology, Brazil, 4446.

Basei, M.A.S., McReath, I. and Siga Jr., 1998, The Santa Catarina Granulite Complex of Southern Brazil: a review.Gondwana Research, 1: 383-391.

Bettencourt, J.S., Tosdal, R.M., Leite, W.B. and Payolla, B.L., 1999, Mesoproterozoic rapakivi granites of the Rondônia Tin Province, southwestern border of the Amazonian craton, Brazil - I.Reconnaissance U-Pb geochronology and regional implications: Precambrian Research, 95: 4167.

Bilal, E., Nalini, Jr. H.A, Horn, H., Correia Neves, J.M., Giret, A., Fuzikawa, K., Fernandes, M.L., Mello, F., and Moutte, J., 1998, Neoproterozoic granitoids suites of Rio doce region, Brazil: International Conference on Precambrian and Craton tectonics, Ouro Preto-MG, Brazil, Abstracts, p. $41-43$

Boggiani, P.C., 1997, Análise Estratigráfica da Bacia Corumbá (Neoproterozóico) - Mato Grosso do Sul.S.Paulo-SP (Doctoral thesis, Instituto de Geociências da Universidade de S.Paulo), 181p.

Brito Neves, B.B., Fuck, R.A., Cordani, U.G., and Thomaz Filho, A., 1984, Influence of basement stuctures on the evolution of the major sedimentary basins of Brazil: a case of tectonic heritage: Journal of Geodynamics, 1 (3/5): 495-510

Brito Neves, B.B., Van Schmus, W.R., Santos, E.J., Campos Neto, M.C., and Kozuch, M., 1995, O evento Cariris-Velhos na Província Borborema: integração de dados, implicaçıes e perspectivas: Revista Brasileira de Geociências, 25: 279-296.

Brod, J.A., Leonardos, O.H., Menezes, P.R., Albuquerque, M.A.C., Almeida, R., Blanco, S.B., Cardoso, F.B., Romão, P.A., Tallarico, F.H. T., and Thomsen, F.R.P., 1993, Geoquímica da Seqüência Vulcano-Sedimentar de Abadia dos Dourados e Complexo Chapada das Perdizes, Triângulo Mineiro-MG: Revista Escola de Minas, 45: 164-166.

Caby, R., 1994, Precambrian coesite from northern Mali: first record and implications for plate tectonics in the trans-Saharan segment of the PanAfrican belt: European Journal of Mineralogy, 6: 235-244.

Campos Neto, M.C. and Caby, R., 1999a, Neoproterozoic high-pressure metamorphism and tectonic constraint from the nappe system south of the São Francisco craton, southeast Brazil: Precambrian Research, in press.

Campos Neto, M.C. and Caby, R., 1999b, Terrane accretion and upward extrusion of high-pressure granulites in the Neoproterozoic nappes of southeast Brazil: petrologic and structural constraints: Tectonics, in press.

Campos Neto, M.C. and Figueiredo, M.C.H., 1995, The Rio Doce orogeny, Southeatern Brazil: Journal of South American Earth Sciences, 8: 143162.

Castaing, C., Triboulet, C., Feybesse, J.L. and Chévremont, P., 1993, Tectonometamorphic evolution of Ghana, Togo and Benin in the light of the Pan-African/Brasiliano orogeny: Tectonophysics, 218: 323-342.

Cawood, P.A and Leitch, E.C., 1998, Going down: subduction initiation in the proto-Pacific and relationship to end Neoproterozoic global events: Journal of African Earth Sciences, 27 (1A): 42.

Cordani, U.G., Thomaz Filho, A., Brito Neves, B.B., and Kawashita, K., 1985 , On the applicability of the Rb-Sr method to argillaceous sedimen- tary rocks: some examples from Precambrian sequences of Brazil: Giornale Geol.,Bologna, 471: 253-280.

Correia, C.T., Girardi, V.V., Tassinari, C.C.G., and Jost, H., 1997, Rb-Sr and Sm-Nd geochronology of the Cana Brava layered mafic-ultramaic intrusion, Brazil and considerations regarding its tectonic evolution: Revista Brasileira de Geociências, 27(2): 163-168.

Correia, C.T., Jost, H., Tassinari, C.C.G., Girardi, V.A.V. and Kinny, P.D. 1999, Estasian Mesoproterozoic U-Pb ages (SHRIMP II) for the metavolcanosedimentary sequences of Juscelândia and Indaianópolis and for high grade metamorphic rocks of Barro Alto stratform igneous complex, Goiás State, central Brazil: in 2th South American Symposium on Isotope Geology (in press).

Corsini, M., Lambert de Figueiredo, L., Caby, R., Féraud, G., Ruffet, G. and Vauchez, A., 1998, Thermal history of the Pan-African/Brasiliano Borborema Province of northeast Brazil deduced from ${ }^{40} \mathrm{Ar} /{ }^{39} \mathrm{Ar}$ analysis: Tectonophysics, 285, 103-117.

Dallmeyer, R.D. and Lécorché, J.P., $1989,{ }^{40} \mathrm{Ar} /{ }^{39} \mathrm{Ar}$ polyorogenic mineral age record within the central Mauritanide orogen, West Africa: Geological Society of America Bulletin, 101: 55-70.

Ebert, H., Chemale, F., Babinski, M., Artur, A.C., and Van Schmus, W.R., 1996, Tectonic setting and U-Pb zircon dating of the plutonic Socorro complex in the transpressive Rio Paraiba do Sul Shear Belt, SE Brazil: Tectonics, 15: 688-699.

Fernandes, L.A.D., Menegat, R., Costa, A.F.U., Koester, E., Porcher, C.C., Tommasi, A., Kraemer, G., Ramgrab, G.E. and Camozzato, E., 1995 , Evolução tectônica do cinturão Dom Feliciano no escudo Sul-RioGrandense: parte I - uma contribuição a partir do registro geológico.Revista Brasileira de Geociências, 25, 351-374.

Ferreira Filho, C.F., Kamo, S.L., Fuck, R.A., Krogh, T.E., and Naldrett, A.J., 1994, Zircon and rutile U-Pb geochronology of the Niquelândia layered mafic and ultramafic intrusion, Brazil: constraints for the timing of magmatism and high grade metamorphism: Precambrian Research, 68: 241255.

Figueiredo, M.C.H. and Campos Neto, M.C., 1993, Geochemistry of the Rio Doce magmatic arc, Southeastern Brazil: Anais da Academia Brasileira de Ciências, 65: 63-81.

Fischel, D.P., Pimentel, M.M., and Fuck, R., 1999, Dados Sm-Nd preliminares da unidade metavulcâno-sedimentar de Silvânia: evidência de uma abertura oceânica há 1,0 Ga na Faixa Brasília: in Simpósio de Geologia do Centro-Oeste, 10, SBG-Brasilia, submitted.

Fonseca, M.A., Dardenne, M.A., and Uhlein, A., 1995, Faixa Brasília Setor Setentrional: estilos estruturais e Arcabouço Tectônico: Revista Brasileira de Geociências, 25 (4): 267-278

Fragoso Cesa, A.R., and Machado, R., 1997. Neoproterozoic terrans of the central Gaucho Shield: in 1st South American Symposium on Isotope Geology, Campos do Jordão, S. Paulo, Extended Abstracts, p. 65-67.

Fuck, R.A., Jardim de Sá, E .F., Pimentel, M., Dardenne, M.A., and Soares, A.C.P., 1994, As faixas de dobramentos marginais do Cráton do Sãfrancisco; síntese dos conhecimentos: in: Dominguez, J.M.L.and Misi, A.(eds.) O Cráton do São Francisco. SBG-SGM-CNPq, Salvador, pp.161-185.

Frimmel, H.E., Almond, J. and Gresse, P.G., 1998, Gariep belt and Nama basin, in Excursion Guidebook, Gondwana-10, Department of Geological Sciences, University of Cape Town, 75pp.

Gaucher, C., Sprechmann, P. and Montaña, J., 1998, New advances in the geology and paleontology of the Vendian to Cambrian Arroyo del Soldado Group of the Nico Pérez terrane of Uruguay: N. Jb. Geol. Paläont. Mh., 3 , in press.

Guimarães, E.M., 1997, Estudos de proveniência e diagênese, com ênfase na caracterização dos filosilicatos dos Grupos Paranoá e Bambuí, na região de Bezerra-Cabaceiras.Brasília-DF (Doctoral thesis, Instituto de Geociências da Universidade de Brasília), $250 \mathrm{p}$.

Harara, O.M., Basei, M.A.S. and Siga Jr.O., 1997, Geochronological and geochemical data on the transition zone between Luis Alves and Atuba complexes, south Brazil, in 1th South American Symposium on Isotope Geology, Brazil, 134-136.

Hartmann, L.A., Leite, J.A.D., McNaughton, N.J., Groves, D.I., Silva, L.C. and Remus, M.V.D., 1999, The impact of the SHRIMP geochronology on understanding the tectonic and metallogenetic evolution fo southern Brazil, in 2nd South American Symposium on Isotope Geology, Argentina (in press)

Helwig, J.E., 1974, Eugeosynclinal basement and a collage concept of orogenic belts: Soc.Econ.Paleontol.Mineral., Spec.Publ., 19: 359-376.

Hoffman, P.F,.1991, Did the breakout of Laurentia turn Gondwanaland inside out? Science, 252: 1405-1412

Hoffman, P.,F., Kaufman, A.,J., Halverson, G.,P. and Schrag, D.,P., 1998, A Neoproterozoic snowball Earth: Science, 281: 1342-1346. 
Jezek, P., Willner, A.P., Münster, and Acenolaza, F.G., 1985, The Puncoviscan trough - a large basin of late Precambrian to Early Cambrian age on the pacific edge of the Brazilian Shield: Geologische Rundschau, 74 (3): 573-584.

Knoll, A.H. and Walter, M.R., 1992, Latest Proterozoic Stratigraphy and Earth History: Nature, 356: 673-678.

Koutschobey, B. and Hieronimus, B., 1996, Origem e significado geotectônico dos metassedimentos e meta-ultramafitos da Serra do Quatipurú (Pará), in Congresso Brasileiro de Geologia, 39, Salvador-BA. SBG.Anais, v.6, p.22-25.

Machado, N., Valladares, C, Heilbron, M., and Valeriano, C., 1996, U-Pb geochronology of the central Ribeira Belt (Brazil) and implications for the evolution of the Brasiliano Orogeny: Precambrian Research, 79: 347361.

Moura, C.A.V. and Souza, S.H.P., 1996, Síntese dos dados geocronológicos das rochas do embasamento do cinturão Araguaia e suas implicações estratigráficas: in Congresso Brasileiro de Geologia, 39, Salvador-BA, Anais, 6, p.31-35

Moura, C.A.V. and Gaudette, H.E., 1993, Zircons ages of the basement orthogneisses of the Araguaia Belt, north-cental Brazil: in Congresso Brasileiro de Geoquímica, 4, Brasília.SBGq, Anais, p.232-235.

Park, J.K., 1994, Palaeomagnetic constraints on the position of Laurentia from middle Neoproterozoic to Early Cambrian times: Precambrian Research, 95-112.

Pedrosa-Soares, A.C., Noce, C.M., Vidal, P., Monteiro, R.L.B.P., and Leonardos, O.H., 1992, Toward a new tectonic model for the Late Proterozoic Araçuaí (SE Brazil) West Congolian (SW Africa) belt: Journal of South American Earth Sciences, 6: 33-47.

Pedrosa-Soares, A.C., Vidal, P., Leonardos, O.H., and Brito Neves, B.B., 1998, Neoproterozoic ocenic remnants in easthern Brazil: further evidence and refutation of an exclusively ensialic evolution for the AraçuaíWest Congo orogen: Geology, 26: 519-522.

Pimentel, M.M. and Fuck, R.A., 1992, Neoproterozoic crustal accretion in Central Brazil: Geology, 20(4): 375-379.

Pimentel, M.M., Fuck, R.A., and Botelho, N.F., 1999b, Granites and the geodynamic history of the Neoproterozoic Brasilia belt, Central Brazil: a review: Lithos, 46: 463-483

Pimentel, M.M., Dardenne, M.A.Viana, M.G., Gioia, S.M., Junges, S., and Seer, H.J., 1999a, Nd isotopes and the provenance of sediments of the Neoproterozoic Brasília Belt, Central Brazil: geodynamic implications, in 2nd South American Symposium on Isotope Geology, Argentina (in press)

Pimentel, M.M., Fuck, R.A., and Fischel, D.P., 1999c, Estudo isotópico SmNd regional da porção central da Faixa Brasília, Goiás: implicações para a idade e origem dos granulitos co Complexo Anápolis-Itauçu e sedimentos do Grupo Araxá: Revista Brasileira de Geociências, 29 (in press)

Pimentel, M.M., Whitehouse, M.J., Viana, M.G., Fuck, R.A., and Machado, N., 1997, The Mara Rosa arc in the Tocantins Province: further evidence for Neoproterozoic crustal accretion in Central Brazil: Precambrian Research, 81:299-310.

Porada, H., 1989, Pan-African rifting and orogenesis in Southern to Equatorial Africa and Eastern Brazil: Precambrian Research, 44: 103-136.

Ramos, V.A, 1988, Late Proterozoic-early Paleozoic of south America - A collisional history: Episodes, 11 (3): 168-174.

Rapela, C.W., Pankhurst, R.J., Casquet, C., Baldo, E., Saavedra, J., Galindo, C., Fanning, C.M., 1998, The Pampean Orogeny of southern protoAndes: Cambrian continental collision in the Sierras de Córdoba: in Pankhurst, R.J.and Rapela, C.W., (eds) The Proto-Andean Margin of Gondwana.Geological Society of London, London, Special Publications, 142, 181-217

Rapela, C.W., Pankhurst, R.J., Casquet, C., Baldo, E., Saavedra, J., and Galindo, C., 1998, Early evolution of the Proto-Andean margin of South America: Geology, 26(8): 707-710

Ribeiro, A., Trouw, R.A.J., Andreis, R. R., Paciullo, F.V.P., and Valença, J., 1995, Evolução das bacias Proterozóicas e o termo-tectonismo Brasiliano na margem sul do cráton do São Francisco: Revista Brasileira de Geociências, 25: 235-248.

Rogers, J.J.W., 1996, A history of the continents in the past three billions years: Journal of Geology, 104: 91-107

Sato, K, 1998, Evolução crustal da Plataforma Sul Americana com base na Geoquímica Sm-Nd.S.Paulo-SP (Doctoral Thesis, Instituto de Geociências, Universidade de S.Paulo), 301 p.

Seer, H.J., Dardenne, M.A., and Fonseca, M.A., 1998, Deformation and tectonic framework of the Meso/Neoproterozoic Units of the southern Brasilia Fold Belt: Implications on the geotectonic evolution: in International Conference on Precambrian and Craton Tectonics, ouro PretoMG.Abstracts, 57-61.
Sengôr, A.M.C., 1990, Plate tectonics and orogenic research after 25 years: A Tethyan perspective: Earth Science Review, 27: 1-201.

Siga, Jr.O., Basei, M.A.S., Sato, K., Citroni, S.B., Reis Neto, J.M., Weber, W., Harara, O.and Sproesser, W.M., 1999, Post-orogenic magmatism and sedimentation in Neoproterozoic extensional regimes in the Brazilian southern region, in 2th South American Symposium on Isotope Geology, Argentina (in press).

Silva, L.C., Macambira, M.J.B., Hartmann, L.A. and Chemale Jr.F., 1997, $\mathrm{Pb}-\mathrm{Pb}$ zircon evaporation age and petrology of the strike-slip-related Paulo Lopes granite, Southern Brazilian granitic province: in 1th South American Symposium on Isotope Geology, Brazil, 309-311.

Silva, L.C., Hartmann, L.A., McNaughton, N.J., and Fletcher, I.R., 1998. SHRIMP U/Pb zircon dating of Neoproterozoic granitic magmatism and collision in the Pelotas Batholith, Southernmost Brazil, International Geology Review, 41: 531-551.

Söllner, F. and Trouw, R.A.J., 1997, The Andrelândia depositional cycle (Minas Gerais/Brazil), a post-Transamazonic sequence south of the São Francisco craton: evidence from U-Pb dating on zircons of a metasediment: Journal of South American Earth Sciences, 10: 21-28.

Stanistreet, I.G., Kukla, P.A. and Henry, G., 1991, Sedimentary basinal responses to a Late Precambrian Wilson cycle: the Damara orogen and Nama foreland, Namibia: Journal of African Earth Sciences, 13: 141-156.

Stern, R.J., 1994, Arc assembly and continental collison in the Neoproterozoic East African orogen: implications for the consolidation of Gondwanaland: Annual Reviews of Earth and Planetary Sciences, 22: 319-351.

Strieder, A.J. and Nilson, A.A., 1992, Mëlange ofiolítica nos metassedimentos do Grupo Araxá de Abadiânia (GO) e implicações tectônicas regionais: Revista Brasileira de Geociências, 22(2):204-205.

Teixeira, N., 1996, Assoalho Oceânico no complexo Ultramáfico do quatipuru (PA).Implicações tectônicas para a Faixa Móvel Araguaia: in Congresso Brasileiro de Geologia, 39, Salvador-BA, Anais, 6: 117-120.

Thomaz Filho, A., Kawashita, K., and Cordani, U.G., 1996, The deposition of the Bambui Group within the context of the regional tectonic evolution: in 30th International Geologic Congress, IUGS.Abstracts, 2: p.49.Beijing.

Tommasi, A., Vauchez, A., Fernandes, L.A.D., and Porcher, C.C., 1994, Magma-assisted strain localization in an orogen-parallel transcurrent shear zone of southern Brazil: Tectonics, 13: 421-437.

Töpfner, C., 1996, Brasiliano-granitoide in den bundesstaaten São Paulo und Minas Gerais, Brasilien-eine vergleichende studie: Münchner Geologische Hefte, 17: 1-258.

Trompette, R., 1994, Geology of Western Gondwana (2000-500 Ma): A.A. Bakelma Publishers, Rotterdam, $350 \mathrm{p}$

Trouw, R.A.J., Ribeiro, A. and Paciullo, F.V.P., 1986, Contribuição à geologia da Folha Barbacena-1:250.000, in: 34th Congresso Brasileiro de Geologia, 2: 974-984.

Tupinambá, M., Teixeira, W., Heilbron, M. and Basei, M.A.S., 1998, The Pan-African Brasiliano arc-related magmatism at the Costeiro Domain of the Ribeira Belt, southeastern Brazil: New geochronological and litogeochemical data: International Conference on Precambrian and Craton Tectonics, Ouro Preto-MG, Abstracts, p.12-14.

Uhlein, A., Trompette, R.R. and Egydio-Silva, M., 1998, Proterozoic rifting and closure, SE border of the São Francisco Craton, Brazil: Journal of South American Earth Sciences, 11: 191-203.

Valeriano, C.M., Simıes, L.S.A., Teixeira, W., and Heilbron, M., 1998, Southern Brasilia Belt ( SE Brazil): Thrust-discontinuities and evolution during the Neoproterozoic Brasiliano orogeny, in International Conference on Precambrian and Craton Tectonics, Ouro Preto-MG, Abstracts, p.62-65.

Van Schmus, W.R., Brito Neves, B.B., Hackspacher, P.C., and Babinski, M., $1995, \mathrm{U} / \mathrm{Pb}$ and $\mathrm{Sm} / \mathrm{Nd}$ geochronologic studies of the eastern Borborema Province, Northeastern Brazil: initial conclusions: Journal of South American Earth Sciences, 8 (3/4): 267-288.

Unrug, R., 1997, Rodinia to Gondwana: The Geodynamic Map of Gondwana Supercontinent Assembly.GSA Today, 7 (1): 1-5

Weber, W., Basei, M.A.S., Siga Jr.O., Sato, K., Passarelli, C, and Prazeres Filho, H., 1999, U-Pb ages in zircon from rocks of alkaline affinity from the Carsoso Island, southeast of São Paulo State, in 2th South American Symposium on Isotope Geology, Argentina (in press).

Weil, A.B., Van der Voo, R., Mac Niocaill, C. and Meert J.G., 1998, The Proterozoic supercontinent Rodinia; paleomagnetically derived reconstructions for 1100 to 800 Ma: Earth and Planetary Science Letters, 154: 1324.

Wiedmann, C., Mendes, J.C., Moura, J.C., Nascimento, R.C.C., and Ludka, L.P., 1997, Granitoides of the Espirito santo Magmatic Arc: International Symposium on granites and Associated Mineralizations- ISGAM II, Salvador-BA, Brazil, Excursion guide, p.57-76 
Wiedmann, C. and Mendes, J.C., 1993, Field evidence of magma mixing in the late Brasiliano arc of Espirito Santo, Brazil: Workshop Magmatismo Granítico e Mineralizaçıes Associadas.Academia Brasileira de Ciências, Publicação Especial: 99-116

Zaine, M.F., and Fairchild, T.R., 1992, Consideraçes paleoambientais sobre a Formação Araras, Faixa Paraguai, Estado de Mato Grosso: in Congresso Brasileiro de Geologia, 37, S.Paulo.Boletim de Resumos Expandidos, SBG, v.2, 474-475.

\section{Benjamim Bley de Brito Neves got} his Ph.D. at the University of São Paulo (USP) in 1975. During the last 37 years, he worked on geology aspects of the Borborema Province, including geological mapping, hydrogeology, tectonics, and isotope geology. Since 1984 he has worked at the São Paulo University, where he is Full Professor. Since 1996 he has been member of the Brazilian Academy of Sciences. Presently he is the Brazilian representative at the Subcommission on Precambrian Stratigraphy of the IUGS.

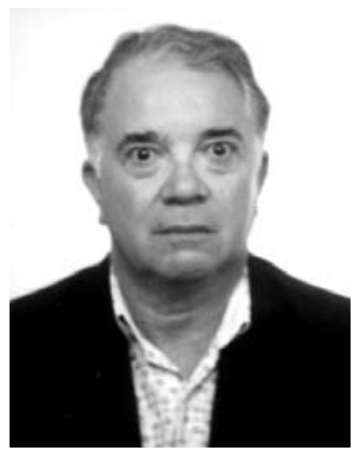

Mario da Costa Campos Neto got his Ph.D at the University of Paris VI in 1979 and at the University of São Paulo in 1991. He did post-doctoral studies in the University of Montpellier-II, France, between 1997-1998. Currently he is Associate Professor of the University of São Paulo (USP). His main research areas include structural geology, tectonics, and metamorphism. For the last 20 years he has worked in the Mantiqueira and Borborema Orogenic Systems, that resulted in several publications.

Fuck R. A. got his D.Sc. at the University of São Paulo (USP) in 1973 and did post-doctoral studies in the University of Durham, UK in 1975. Presently he is Full Professor of the University of Brasilia, regional editor of the Journal of South American Earth Sciences and member of the Brazilian Academy of Sciences. His main research areas are precambrian geology, petrology, and isotope geology, with special focus in the Brasilia Fold Belt of the Tocantins Province. He has already published over 60 papers in national and international magazines about geological aspects of this region.
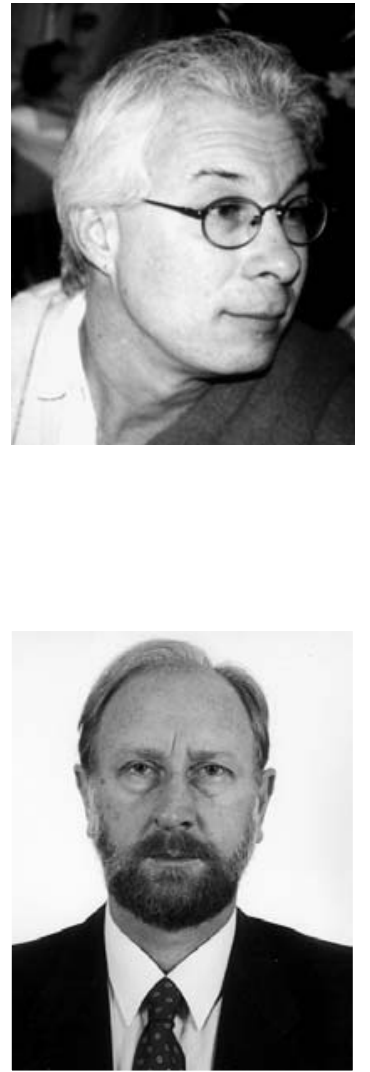